http://dx.doi.org/10.4314/jae.v18i2.5

\title{
Adoption of Improved Aquaculture Management Practices by Cluster Fish Farmers in Delta State, Nigeria
}

\author{
Aphunu $\mathrm{A}^{1^{*}}$ and A. E. Agwu ${ }^{2}$ \\ ${ }^{1}$ Department of Agricultural Extension and Management, Delta State Polytechnic. Ozoro. \\ P. M. B. 5, Ozoro, Delta State. \\ 2 Department of Agricultural Extension, University of Nigeria, Nsukka, Enugu State, \\ Nigeria. \\ E-mails: agwuekwe@hotmail.com; tonyaphunu@yahoo.com \\ *Mr. Anthony Aphunu died in May 2014 as a result of ill-health.
}

\begin{abstract}
The adoption of proven fish production management practices portends many economics and social implications. Interview schedule was employed to generate primary data from 146 respondents in the four cluster fish farms (estates) in two local government areas and analyzed with descriptive and inferential statistics. Information on socio economic characteristics revealed that most of the respondents were in the active age bracket of 30-40 years, well educated and small scale fish farmers with fewer years of experience members at fish farmers association and married. Fellow farmers (57.5\%) were major source of information on fish farming since the farmers were brought together under the umbrella body of fish farmers' association. The study further revealed a low adoption level for all the management practices on adoption index of 0.43 which means that the farmers had only $43 \%$ adoption of the practices. Age, education and fish farming experience of fish farmers correlate with the adoption of some improved aquaculture management practices. In view of prevailing evidence regular training and workshops to update the knowledge and information on modern aquaculture practices should be organized for fish farmers.
\end{abstract}

Key words: Adoption, improved aquaculture management practices, cluster fish farmers.

\section{Introduction}

FAO (2004) reported that fishing contributes about $5 \%$ of the per capita animal in-take and employs about 8 million people worldwide. Fish is also an important and indispensable source of protein, providing at least 50 percent of the essential animal protein and mineral intake for 400 million people from the poorest African and South Asian countries (Multi-Agency Brief (MAB), 2009). Fisheries offer a key entry point to reach millions of poor people of the world including Nigeria. It assists in increasing people's income, improving the nutrition and health of families and acts as active agent of economic development and social change (Ifejika, Akinbile, Ifejika and Oladeji, 2008). In Nigeria, fish production is from both internal and external sources. Of the internal sources, aquaculture is the second most important after artisanal fisheries and supplied between $5-13.5 \%$ of total domestic fish production between 2000 and 2007 (Federal Development of Fisheries (FDF), 2007). Aquaculture or fish farming has the potential of revising the 
trend of fish importation. This requires capitalizing on adoption of aquaculture technologies to strengthen production to increase fish food security and economic growth at individual and national levels.

Akinbile and Alabi (2010) stated that the enhancement of local fish production can be brought about by improving capacity in terms of enhancing access to and utilization of information. In the same vein, it requires that the technical knowledge and capabilities of fish famers be regularly updated through enhanced information seeking behaviour. Aquaculture, as in other areas or sub-sectors of agriculture has certain complexities. For example, the provision of fingerlings to stock ponds, pond fertilization and food provision require considerable sophistication (Ajieh, 2004). The farmer therefore needs competency in knowledge, skills and techniques involved in the efficient management of fish to maximize production. Farmers' competences in aquaculture could be enhanced through persuasion to adopt agricultural innovations, by transferring technology and knowledge from scientists to farmers to trigger development (Agbamu 2006). With regards to the cluster fish famers (group of fish farmers closely located in one location) of Delta State, there is dearth of empirical data on the state of adoption of improved aquaculture management practices. The overall purpose of the study was to examine the adoption of improved aquaculture management practices by cluster fish farmers in Delta State. Nigeria.

Specifically, the study was designed to:

1. describe the socio economic characteristics of cluster fish farmers in Delta State;

2. identify sources of information on aquaculture technologies; and

3. ascertain the level of adoption of aquaculture management practices on fish farming.

\section{Methodology}

The study was conducted in Delta State, South-South geopolitical zone of Nigeria. The state lies between latitude $5^{\circ} 00^{\prime}$ and $6^{\circ} 30^{\prime}$ North and longitudes $5^{\circ} 00^{\prime}$ and $6^{\circ} 45^{\prime}$ East. The state is generally low-lying without hills but with a wide coastal belt interlaced with rivulets streams and rivers which form part of the Niger Delta. The distribution of vegetation varies from mangrove swamp along the coast to fresh water swamp forests and a derived savannah in the north. The population for the study comprised a cross section of all cluster fish farmers in Delta State, located in Uvwie and Warri-South Local Government Areas (L.G.As) of the state, respectively. A total of four cluster fish farms were identified: Ekpan cluster farms (made up of 2000 fish farmers having about 6000 fish ponds), Ugboroke layout (800 fish farmers with about 2000 fish ponds); New layout (200 fish farmers with 1000 fish ponds), and Ubeji cluster which comprised of 200 fish farmers having about 1000 fish ponds. The cluster fish farmers are effectively organized into a fish famers' cooperative society known as Ekpam Fish Famers Cooperative Society (EFFC). Proportionate sampling procedure was used to select $5 \%$ of the fish farmers from each cluster. This gave a total of 160 fish farmers out of the registered number of 3200 cluster fish farmers. However, only 146 of them gave valid responses which were used for analysis. Data for the study were collected through a semi-structured interview schedule. 
To determine the adoption levels of aquaculture management practices by the respondents a 5-point Likert-type adoption scale was used for each of the management practices listed. The respondents were asked to indicate their adoption stages for the various practices using the five steps (aware, interest, evaluation, trail and adoption model with values of 1,2,3,4 and 5 respectively (Agwu, 2006).

The adoption indices of the respondents were calculated as follows:

a) Computation of the total mean (M) adoption score per management practice. This was computed by dividing the total adoption score by the number of respondents involved.

b) Computation of the grand mean adoption score. This was calculated by adding all the mean adoption scores and dividing by the number of innovations considered.

c) Computation of the adoption index. This was carried out by dividing the grand mean (M) adoption score by 5(i.e. the 5 -stages of adoption).

Data were analyzed using both descriptive and mean statistics. Objectives one and two were achieved using percentage, while objective three was analyzed by means scores.

\section{Results and Discussion}

\section{Personal characteristics of respondents}

The result in Table 1 show that majority (65.8\%) of the respondents were males which implies that males dominated fish farming in the area. This could be as a result of the laborious nature of fish farming operations which are very tedious for females to handle. Ogunlade (2007) noted that management practices in fish farming may be too tedious for females which the males have stamina to handle. The mean age was 34.7 years, an indication that young and agile able bodied rather than old, inactive farmers were involved in fish farming. The finding has implication for extension organizations to target younger fish farmers who are still strong and full of energy to make meaningful impact in fish production. Majority (68.5\%) of the respondents were married and about $73 \%$ of them had tertiary education. The level of education is sufficient enough to support adoption of technology through information sharing and distribution. The result tallies with the assertions of Imo and Essien (2005) that education increases adoption and enhances farmers' ability to understand and evaluate new production techniques. The result further shows that majority $(64.4 \%)$ of the respondents had 15 years fish farming experience while about a third (33.6\%) of them had between 6 and 10 years' experience, which implies that the entrance rate of people into fish farming is rapid in the recent past. Ofuoku et al. (2008) had similar result in their study and noted that this may be due to the potentials of fish farming as a profitable venture and source of protein. The small proportion (2.1\%) who had $11-15$ years of fish farming experience could serve as vital source of information on management practices to other farmers. Majority of the fish farmers operate on a small scale level, having between 1 and 5 fish ponds. The finding is in agreement with Olapade, Taiwo and Odunaya (2005) and Ezinwa, Ayinla and Ajana (2003) on classification of aquaculture scale of practice in Nigeria. On membership of association, only $24 \%$ belonged to cooperative societies and majority $(67.1 \%)$ are into fish farmers association. Farmers belonged to fish farmers association because it supports information dissemination among members. Those benefits especially exchange of 
information on improved management practices. The result further shows that extension agents $(21.2 \%)$ were the next significant source of information for the fish farmers. A critical look at the result shows that these dominant sources are interpersonal sources. The result tallies with the finding of Opara (2008) who noted that interpersonal communication is more robust with built-in feedback mechanism. It is however instructive to note that the respondents never indicated any of the electronic media (Radio, Television Internet) as sources of information. While the state had programmes on radio and television targeted at farmers, the respondents claimed ignorance and never indicated them as source of information. Daudu et al. (2009) 'findings also corroborate this fact that the internet and library are still an elitist communication media for most people. The implication of this is that stakeholders in the provision of agricultural information need to do more in the area of information delivery and dissemination to fish farmers. Giving farmers access to a variety of information sources, which are accessible, affordable, relevant and reliable is the ultimate aim of providing agricultural information services (Gibbon and Warren 1991).

Table 1: Percentage distribution of respondents by source of information on fish farming

\begin{tabular}{ll}
\hline Source & Percentage (\%) \\
\hline Fellows farmers & 57.5 \\
Extension agents & 21.2 \\
Personal experience & 6.8 \\
Workshop/seminars & 5.5 \\
Relations, neighbours and friends & 4.8 \\
Written sources (newspapers, magazines bulletins) & 4.1 \\
Television & - \\
Radio & - \\
Internet & - \\
\hline
\end{tabular}

Sources: Field survey, 2011

\section{Adoption of improved aquaculture practices}

Results in Table 2 reveal the adoption levels of the farmers on aquaculture management practices. A greater proportion of the famers have not adopted and used improved aquaculture management practices in their production and many are in the awareness and interest stages, respectively. For example, in pond clearing only 3 farmers said they adopted and used improved pond clearing techniques, while the majority (86) said they are only aware of the practice. This is the scenario with all the aquaculture management practices. Overall, the result reveals low adoption levels of the farmers on the management practices. The grand adoption mean for all the management practices was 2.15, which implies that the farmers were still at the interest stage on the 5-point adoption scale. Furthermore an adoption index of 0.43 for the management practices means that the farmers had only $43 \%$ adoption of the practices. The low adoption of these management practices could be attributed to paucity of technical information on improved aquaculture management practices among the fish farmers studied. The result of the finding is not surprising since majority of the farmers relied on their fellow farmers instead of extension agents as a source of information and advice (Ozowa, 1995). The low 
adoption level has implication for extension services delivery in the state particularly to the fish farming sector where improved innovations are sine qua non to increased production.

Table 2: Distribution of respondents on adoption of management practices

\begin{tabular}{|c|c|c|c|c|c|c|c|c|c|}
\hline $\begin{array}{l}\text { Improved Management } \\
\text { Practices }\end{array}$ & 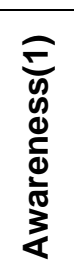 & 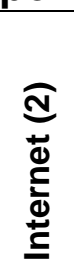 & 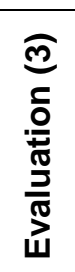 & 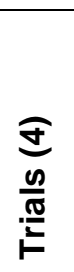 & 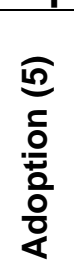 & $\begin{array}{l}\text { Total } \\
\text { Adoption } \\
\text { Score }\end{array}$ & $\begin{array}{l}\text { Adoption } \\
\text { mean } \\
\text { Score }\end{array}$ & $\begin{array}{l}\text { Grand } \\
\text { Mean } \\
\text { Score }\end{array}$ & $\begin{array}{l}\text { Adoption } \\
\text { Index }\end{array}$ \\
\hline Pond clearing & 86 & 34 & 10 & 13 & 3 & 251 & 1.72 & & \\
\hline Fertilization & 78 & 34 & 16 & 10 & 8 & 270 & 1.85 & & \\
\hline Water quality/treatment & 67 & 30 & 24 & 16 & 9 & 308 & 2.10 & & \\
\hline $\begin{array}{l}\text { Acclimatization of } \\
\text { fingerlings }\end{array}$ & & & & & & & & & \\
\hline stocking & 56 & 47 & 27 & 10 & 6 & 301 & 2.06 & & \\
\hline Stocking operation & 30 & 75 & 15 & 15 & 11 & 340 & 2.32 & & \\
\hline Weed control & 33 & 59 & 27 & 12 & 15 & 344 & 2.43 & & \\
\hline Disease control & 36 & 53 & 22 & 14 & 21 & 369 & 2.52 & & \\
\hline Liming & 57 & 34 & 30 & 11 & 14 & 329 & 2.25 & 2.15 & 0.43 \\
\hline Clearing of pond banks & 37 & 66 & 16 & 15 & 12 & 337 & 2.31 & & \\
\hline \multicolumn{10}{|l|}{ Routine check on fish } \\
\hline Performance & 71 & 42 & 28 & 2 & 3 & 262 & 1.79 & & \\
\hline Pond embankment & 68 & 34 & 32 & 9 & 3 & 283 & 1.94 & & \\
\hline Supplementary feeding & 61 & 33 & 29 & 15 & 8 & 314 & 2.15 & & \\
\hline Checking of pond fertility & 43 & 41 & 39 & 15 & 8 & 342 & 2.34 & & \\
\hline Fish spawning operation & 75 & 40 & 37 & 6 & 8 & 330 & 2.26 & & \\
\hline Repair of leaks and & & & & & & & & & \\
\hline cracks on ponds & 31 & 67 & 31 & 12 & 5 & 331 & 2.27 & & \\
\hline
\end{tabular}

\section{Conclusion and Recommendation}

Evidence from the study confirms that adoption of various improved aquaculture management practices has very low adoption index of 0.43 (43\% adoption) which showed low adoption rate by the farmers. This correlates with the low reliance on institutionalized sources of information such as the extension services by the farmers for relevant information needed to promote adoption. The implication of the findings is that fish production in the state from this sector may not be able to cope with the increasing demand from the ever expanding population. The study recommends that, given the facts that individuals with timely, proven and appropriate information are likely to make well informed and better decisions than other wise, the timely adequate and consistent provision of proven information be made available to the fish farmers. In line with this, the existing information sources especially the extension services need to be strengthened to perform this role in addition to sensitizing the farmers to be responsive to institutionalized information sources. 


\section{References}

Agbamu, J.U. (2006), Essentials of Agriculture Communication in Nigeria. Lagos Malthouse Press . Ltd.

Agwu, A.E. (2000 a). Adoption of improved oil palm production and processing technologies in Arochukwu Local Government Area of Abia State, Nigeria Agroscience Journal of Tropical Agric Food. Environment and Extension. Vol. 5. No 1, pp 26-35.

Aina, I.O. (1991) Information for Successful Agriculture. World Libraries. Retrieved October 20, 2010, from http://www.worlib.org/

Aina, I.O. (1995). Agricultural Information in Africa. Ibadan: Third Publisher.

Ajieh, P.C. (2004). Technology Needs and Transfer in Homestead Fish Culture Development in Delta State, Nigeria. Pre-PHD proposal seminar presented at the Department of Agricultural Extension, University of Nigeria Nsukka.

Akinbile, I. A. and Alabi, O.F. (2010). Use of ICTs among fish farmers of Oyo State. Journal of Agricultural Extension, Vol. 14 (1) pp. 25-35.

Duadu, S. Chado, S.S. and Igbashal (20090. Agricultural information sources utilized by farmers in Benue State, Nigeria Available: www.patnuskjournal.net/currentissue.

Ezenwa, B.I. Ayila, O.A. and Ajana A.M. (2003) Agricultural Research Technology Transfer for Rural Development. Proceedings of $16^{\text {th }}$ Annual conference of FISON, held at Maiduguri, 4-6 November, pp. 1-7.

Federal Department of Fisheries (FDF) (2007). Fisheries Statistics of Nigeria. Federal Department of Agriculture and Rural Development Abuja.

Food and Agriculture Organization of the United Nation (F.A.O) (2004). The State of World Fisheries and Aquaculture F.A.O Rome, 153pp.

F.A.O. (2005). Increasing the contribution of small-scale fisheries to poverty alteration and food security, F.A.O Technical Guidelines for Responsible Fisheries. N0. 104, F. A.O Rome, $79 \mathrm{pp}$.

Gibbon, J. and Warren, M.F. (1991). Barriers to adoption of on-farm computers in England. Farm Management, Vol. 8, N0 1, pp 9-15.

Ifejika, P.I., Akinbile, L. A., Ifejika, I.I., and Oladeji, J.O. (2008). The socio-economics effects on adoption of aquaculture technologies among fish farmers in Anambra State, Nigeria. Journal of Agricultural Extension. Vol. 11 pp 74-87.

Imoh, A.N. and Essien, M.U. (2005), Adoption of improved cassava varieties among small-scale farmers in Ikot-Ekpene Agricultural zone, Akwa lbom State. Nigeria, 
Proceedings, $39^{\text {th }}$ Annual Conference of the AESON, held at the University of Benin. Benin City, October $9^{\text {th }}-13^{\text {th }}$. pp 1-7.

Irokwe, A.G. Asiedu, R. and Chinaka, E.C. (2007), Women farmers participation in yam mini-sett adoption in South Eastern Nigeria. Global Approach to Extension Practice. Vol. 3, No 2, pp 66-69.

Ofuoku, A.U., and Ideh, V. (2006) Comparative analysis of co-operative and non cooperative fish farmers in the central Agro-Ecological zone of Delta State Nigeria Extension Farming Systems Journal. Vol. 2. No 1, pp 97-104.

Ofuoku, A.U., Emah, G. N. and Itedjere, B.E. (2008). Information utilization among rural fish farmers in Central Agricultural zone of Delta State. Nigeria, World Journal of Agricultural Science. Vol. 4 (5) pp. 558-564.

Olapade, O. A, Taiwo, I.O. and Odunaya, O. (2005). A survey of small aquaculture systems in Ogun State. International Journal of Food and Agricultural Research. Vol. 2 No. 1 \&2. Pp $17-25$.

Opara, U. N. (2008) Agricultural information sources used by farers in Imo State, Nigeria. Information Development. Vol. 24 No 24. Pp 289 -295. Available at: http: /www/.sagepub.com/content/24/4/289.ref.html.

Ozowa, V. N. (1995) Information needs of small scale farmers in Africa: the Nigeria example. Quarterly Bulletin of International Specialists. Vol. 40 (1) 